Sf Universidad

:

\title{
BIBLIOTECA
}

Document downloaded from the institutional repository of the University of Alcala: http://dspace.uah.es/dspace/

This is a postprint version of the following published document:

Rey Benayas, J.M. \& Bullock, J.M. 2012, "Restoration of Biodiversity and Ecosystem Services on Agricultural Land", Ecosystems, vol. 15, no. 6, pp. 883-899.

Available at http://dx.doi.org/10.1007/s10021-012-9552-0

(C) 2012 Springer Science
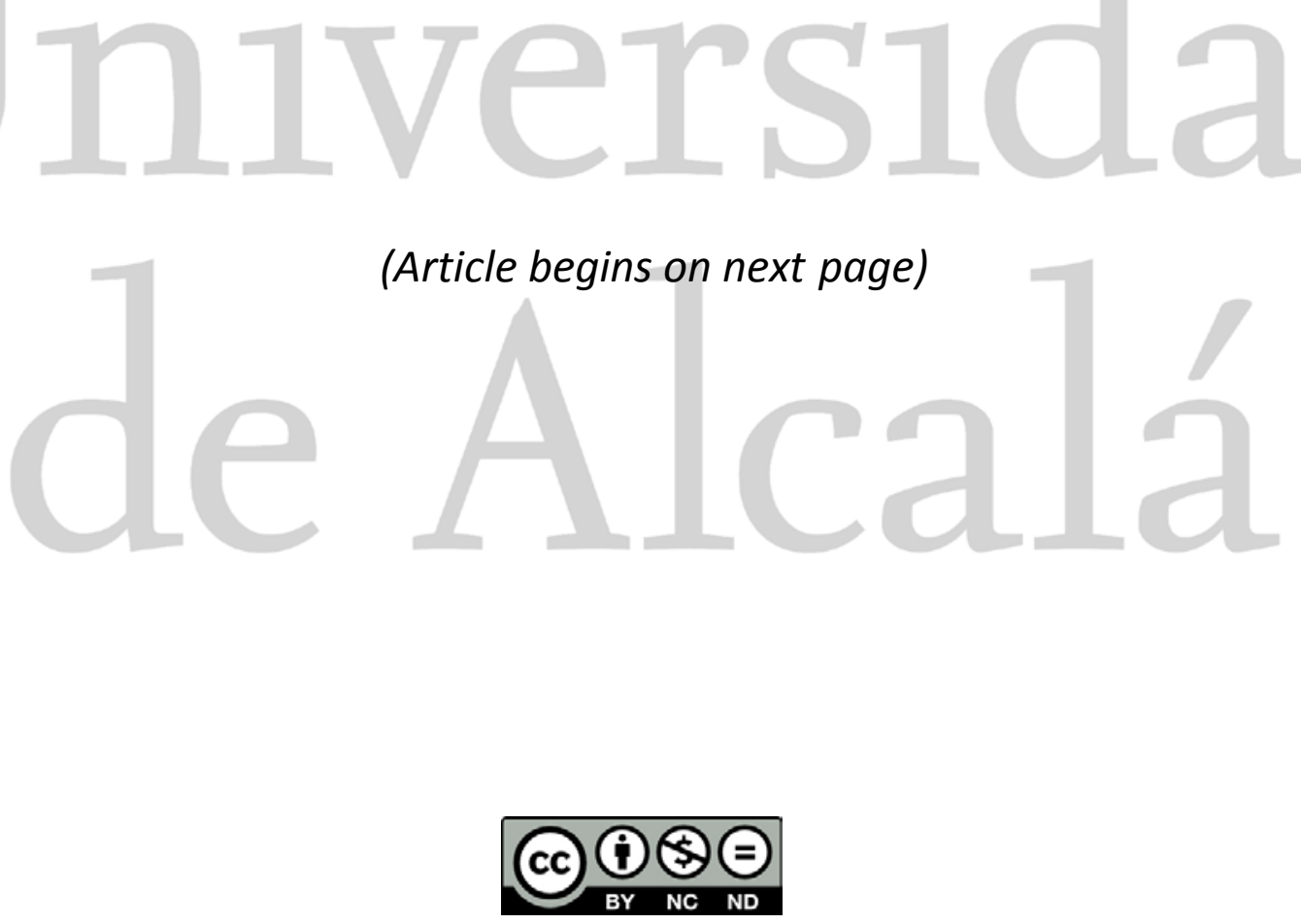

This work is licensed under a

Creative Commons Attribution-NonCommercial-NoDerivatives

4.0 International License. 


\section{Restoration of biodiversity and ecosystem services on \\ 2 agricultural land}

3

4 José $\mathbf{M}^{\mathrm{a}}$ Rey Benayas ${ }^{{ }^{*}}$ and James M. Bullock ${ }^{2}$

5

$6 \quad{ }^{1}$ Departamento de Ecología, Universidad de Alcalá, 28871 Alcalá de Henares, Spain;

$7 \quad{ }^{2}$ Centre for Ecology and Hydrology, Maclean Building, Benson Lane, Crowmarsh

8 Gifford, Wallingford, Oxfordshire, OX10 8BB, UK

$9 \quad *$ Corresponding author; e-mail josem.rey@uah.es

10

11

12

13

14

15

16

17

18

19

20

21

22

23 Description of how each author has contributed to the article: both authors have

24 contributed substantially to the work. J.M. Rey Benayas conceived the study and both

25 J.M. Rey Benayas and J.M. Bullock wrote the paper 


\section{ABSTRACT}

27 Cultivation and cropping are major causes of destruction and degradation of natural 28 ecosystems throughout the world. We face the challenge of maintaining provisioning services while conserving or enhancing other ecosystem services and biodiversity in agricultural landscapes. There is a range of possibilities within two types of intervention, namely "land sharing" and "land separation"; the former advocates the enhancement of the farmed environment, but the latter a separation between land designated for farming vs. conservation. Land sharing may involve biodiversity-based agricultural practices, learning from traditional farming, changing from conventional to organic agriculture and from "simple" crops and pastures to agro-forestry systems, and restoring or creating specific elements to benefit wildlife and particular services without decreasing agricultural production. Land separation in the farmland context involves restoring or creating non-farmland habitat at the expense of field-level agricultural production - e.g. woodland on arable land. Restoration by land sharing has the potential to enhance agricultural production, other ecosystem services and biodiversity at both the field and landscape scale; however, restoration by land separation would provide these benefits only at the landscape scale. While recent debate has contrasted these approaches, we suggest they should be used in combination to maximise benefits. Furthermore, we suggest "woodland islets", an intermediate approach between land abandonment and farmland afforestation, for ecological restoration in extensive agricultural landscapes. This approach allows reconciliation of farmland production,

47 conservation of values linked to cultural landscapes, enhancement of biodiversity, and

48 provision of a range of ecosystem services. Beyond academic research, restoration

49 projects within agricultural landscapes are essential if we want to halt environmental degradation and biodiversity loss. 
52 Keywords: agroforestry, financial support, land separation, land sharing, organic agriculture, reconciliation, secondary succession, tree plantations, woodland islets

\section{INTRODUCTION}

Currently, about $80 \%$ of the planet's surface shows evidence of human intervention (Ellis and Ramankutty 2008). This implies large losses of biodiversity (Butchart and others 2010) and of the variety and amount of all ecosystem services (i.e. the benefits that people obtain from ecosystems) except certain provisioning services (MEA 2005). A large part of such environmental degradation is due to the expansion of the agricultural frontier in many parts of the world together with intensification of farming methods (BirdLife International 2008, FAO 2010, Mulitza and others 2010). For instance, Ellis and Ramankutty (2008) indicated 14 of the World's 21 major biome types which have agricultural use. Predictions suggest that humanity's footprint will expand in the future (Hockley and others 2008; Pereira and others 2010; WWF 2010).

One of the most powerful approaches to countering the negative impacts of agricultural expansion and intensification is ecological restoration. Ecological restoration aims to recover the characteristics of an ecosystem, such as its biodiversity and functions, which have been degraded or destroyed, generally as a result of human activities (Society for Ecological Restoration International 2004). Restoration actions are increasingly being implemented in response to the global biodiversity crisis, and are supported by global agreements such as the Convention for Biological Diversity (CBD) (Sutherland and others 2009). Three major targets of the new CBD strategic plan for

742020 arising from the Nagoya Conference in 2010 are: to eliminate subsidies harmful to 
restore at least $15 \%$ of degraded ecosystems (Normile 2010). Such policy initiatives are useful, but raise questions about our ability to manage and restore ecosystems to supply multiple ecosystem services and biodiversity (Rey Benayas and others 2009; Bullock and others 2011).

Ecosystem management that attempts to maximize a particular ecosystem service often results in substantial declines in the provision of other ecosystem services 82 (Bennet and others 2009). As a consequence, there is often a trade-off between agricultural production vs. other services and conservation of biodiversity (Green and others 2005; Pilgrim and others 2010). Thus, we face the challenge of increasing provisioning services such as food production - by $70 \%$ for 2050 according to FAO (2009) - for an expanding population while simultaneously conserving or enhancing biodiversity and the other types of ecosystem services (e.g. regulating and cultural services) in agricultural systems (Kiers and others 2008). Rey Benayas and others (2009) showed a positive relationship between biodiversity and provision of ecosystem services in restored vs. degraded ecosystems in a wide variety of ecosystems. However,

91 restoration of biodiversity and of services is not the same thing (Bullock and others 92 2011). For instance, especially in agricultural land, concentration on services such as 93 carbon or water retention may be in conflict with biodiversity (Ridder 2008; Cao and others 2009; Putz and others 2009).

In this article, after examining the complex role of agricultural systems in both 96 delivering and harming biodiversity (the "agriculture and conservation paradox"), we

97 review approaches to enhance both biodiversity and ecosystem services in agricultural landscapes. Recent discussions of the future of farming have contrasted "land sharing”sometimes called "environmentally- or wildlife-friendly farming”- with "land

100 separation”. The former advocates the enhancement of the farmed environment, while 
101 the latter advocates a separation of land designated for farming from that for 102 conservation (Green and others 2005; Fischer and others 2008; Hodgson and others 103 2010; Phalan and others 2011). Land separation is usually referred to as "land-sparing”

104 when high-yield farming is combined with protecting natural habitats from conversion

105 to agriculture (e.g. Phalan and others 2011). We will argue that these approaches should 106 not be seen as alternatives, but as representing the range of actions that can be combined 107 to best enhance biodiversity and ecosystem services. On one side, we will examine the 108 potential to produce systems in which agricultural production and conservation or 109 enhancement of biodiversity and of other ecosystem services than agricultural 110 production is in partnership rather than in conflict. We will show an exemplary case 111 study to illustrate examples of existing options to achieve such goal. Cropland has

112 mostly spread at the expense of forest land and natural grassland (Foley et al. 2005).

113 Thus, on the other side, we will focus on forest regrowth and tree plantations on

114 cropland as examples of land separation by natural habitat restoration. Finally, we will 115 discuss the necessity of restoration projects in the real world beyond academic research 116 and the key issues that must be addressed for a wide implementation of such projects. THE AGRICULTURE AND CONSERVATION PARADOX

Few human activities are as paradoxical as agriculture in terms of their role for 120 nature conservation. Agricultural activities are the major source of negative 121 environmental impacts worldwide (Kiers and others 2008). For instance, agriculture: is 122 the main cause of deforestation (FAO 2010); is the major threat to bird species 123 (BirdLife International 2008); accounts for ca. 12\% of total direct global anthropogenic 124 emissions of greenhouse gasses (IPCC 2007); and strongly impacts on soil carbon and 125 nutrients (McLauchlan 2006). Cropland and the grazing land footprints accounted for 
ca. 24\% and 7\%, respectively, of the total human global footprint in 2007 (WWF 2010).

127 These figures vary greatly among countries (Table 1). They are proportionally the 128 lowest, ca. $18 \%$ and 4\%, respectively, in the 31 OECD countries, which include the 129 world's richest economies, and the highest, ca. $36 \%$ and $14 \%$, respectively, in the 53 130 African Union countries, which include some of the world poorest and least developed 131 countries (WWF 2010).

Agricultural land covers over $40 \%$ of the terrestrial surface, to the detriment of natural vegetation cover (Foley and others 2005). At the global scale, the conversion of natural ecosystems to agricultural systems has currently reached a plateau (Figure 1). However, there is a great variation among countries; agricultural land has declined in some whereas it has increased in others - chiefly developing countries that harbour the highest amounts of biodiversity (e.g. Cayuela and others 2006; Table 1). In recent history, farming practices in many areas have become more intensive, and increasing amounts of water, fuel, fertilizers, pesticides, herbicides, and non-native

140 species are used worldwide to enhance production. For example, the global area 141 serviced by irrigation now accounts for ca. 20\% of cultivated land (FAOSTAT 2011; 142 Figure 1). Agriculture is the major form of human water consumption in the world and 143 threatens water security and habitats (Vorosmarty and others 2010). Beyond changes in 144 species richness, agricultural intensification has been shown to reduce the functional 145 diversity of plant and animal communities, potentially imperilling the provisioning of 146 ecosystem services (Flynn and others 2009). Many studies have found negative effects 147 of agrochemicals on biodiversity and ecosystem function (e.g. Rohr and others 2008; 148 Geiger and others 2010). Intensification of land use has brought remnant areas of 149 natural vegetation such as steep hillsides, property boundaries and track edges into 150 mainstream agriculture (Rey Benayas and others 2008). Thus, agricultural expansion 
151 and intensification have greatly increased our food supplies at the global scale, but have

152 damaged biodiversity and other services.

In contrast to these negative perspectives, habitats converted to agricultural

154 activities are often viewed positively in terms of nature conservation due to, for

155 example, creation of landscape mosaics and environmental heterogeneity (Dornelas and

156 others 2009; Oliver and others 2010; Sitzia and others 2010), or because they are

157 threatened habitats that support endangered species and cultural values (Kleijn and

158 others 2006; Lindemann-Matthies and others 2010). In the EU-27, 31\% of Natura 2000

159 sites, a network of protected areas, result from agricultural land management. Several

160 taxa including species of birds, insects and plants, some of them endangered, depend on

161 low-intensity farmland for their persistence (Doxa and others 2010; Kohler and others

162 2011). Thus, regional trends of common farmland birds in Europe show negative trends

163 (-35\% since 1980) and these are today of conservation concern, whereas forest birds

164 show positive trends due to abandonment of agricultural land and afforestation

165 programs (European Bird Census Council 2010). Such declines might affect agricultural

166 production itself. Insects that provide pollination and pest control services in cropland

167 tend to be less common in more intensive landscapes (Tscharntke and others 2005; Potts

168 and others 2010).

169 Agricultural intensification can have a negative impact on the values linked to

170 traditional agriculture, but so can agricultural abandonment and, particularly,

171 afforestation of former cropland (Rey Benayas and others 2007; Sitzia and others 2010).

172 Abandonment of agricultural land has mostly occurred in developed countries in the last

173 few decades (Table 1) and it is currently happening in developing countries with strong

174 rural migration to urban areas such as in Latin America (Rey Benayas and others 2007;

175 Grau and Aide 2008). The European Agrarian Policy is providing subsidies to afforest 
176 land after vineyard extirpation in Spain, an action that is being criticized by

177 conservationists due to negative impacts on aesthetic and other values. The Chinese

178 Grain for Green project is a major, but controversial, project related to afforestation of

179 former cropland (Cao and others 2009; see below). It seems that agriculture, woodland,

180 and biological conservation are in a permanent and irreconcilable conflict, the

181 agriculture and conservation paradox (Rey Benayas and others 2008).

\section{ENHANCING BIODIVERSITY AND ECOSYSTEM SERVICES IN}

\section{AGRICULTURAL LANDSCAPES}

There is a range of possibilities to reverse the negative environmental impacts of agriculture. Some of these options have the potential to enhance biodiversity and ecosystem services including agricultural production, but others may enhance biodiversity and ecosystem services other than agricultural production. They can be considered within two major approaches:

190 (1) Land sharing. We can classify five types of intervention following this approach.

191 Four involve extensive actions on agricultural land with a focus on productivity, i.e.

192 making agriculture more wildlife- (and ecosystem service) friendly: (a) adoption of biodiversity-based agricultural practices; (b) learning from traditional farming

194 practices; (c) transformation of conventional agriculture into organic agriculture; or

195 (d) transformation of "simple" crops and pastures into agro-forestry systems. The 196 fifth (e) involves restoring or creating specific elements to benefit wildlife and 197 particular services without competition for agricultural land use. In practice, these 198 interventions may be carried out concurrently as they are not exclusive (Figure 2).

199 (2) Land separation in the farmland restoration context involves restoring or creating 200 non-farmland habitat in agricultural landscapes at the expense of field-level 
agricultural production - e.g. woodland, natural grassland, wetland, and meadow on arable land. This approach does not necessarily imply high-yield farming of the nonrestored, remaining agricultural land.

204 Next, we will document some examples of these two types of intervention to enhance biodiversity and ecosystem services in agricultural landscapes.

\section{Land sharing}

208 Adoption of biodiversity-based agricultural practices

209 Conservation of existing biodiversity in agricultural landscapes and the adoption of

210 biodiversity-based practices have been proposed as ways of improving the sustainability

211 of agricultural production through greater reliance on ecological goods and services, and

212 with less damaging effects on environmental quality and biodiversity (McNeely and

213 Scherr 2003; Jackson and others 2007). Management of biodiversity, i.e. the biota

214 dwelling in agroecosystems as well as habitats and species outside of farming systems

215 in the landscape (Vandermeer and Perfecto 1995), can be used to benefit agricultural 216 production and enhance ecosystem services.

217 Examples of agrobiodiversity functioning at different hierarchical levels include

218 (Jackson and others 2007): (1) genetic and population characteristics, e.g. the use of 219 traditional varieties and wild species for continuing crop and livestock improvement for increased pest resistance, yield and quality (Cooper and others 2001; Tisdell 2003); (2) community assemblages or guilds that influence agricultural production, such as pest control based on toxin biosynthesis or other plant defences against herbivore attack,

223 crop mixtures, release of natural enemies, and pest suppression by a complex soil food web (Dicke and others 2004) or increased yield following inter-cropping and crop rotation (Chabi-Olaye and others 2005); (3) heterogeneity of biota in relation to 
226 biophysical processes within ecosystems, such as nutrient cycling and retention or

227 carbon accumulation (van Noordwijk 2002); and (4) landscape-level interactions

228 between agricultural and non-agricultural ecosystems that enhance resources for

229 agriculture, and potentially, resilience during environmental change, e.g. agricultural

230 landscapes that are composed of a mosaic of well-connected early and late successional

231 habitats may be more likely to harbor biota that contribute to regulating and supporting

232 services for agriculture, compared to simple landscapes (Elmqvist and others 2003;

233 Bianchi and others 2006).

234

235 Learning from traditional farming practices

236 Traditional farming describes practices that developed through human history to

237 produce a variety of agricultural goods, largely for local use. Forms of traditional

238 farming persist in many parts of the world, particularly in developing countries, but also

239 in more developed countries, where such methods are remnants or have been re-

240 introduced to meet specific needs (Altieri 2004; Kleyer and others 2007). Traditional

241 farming methods are extremely diverse, by their nature, but they often share a number

242 of distinguishing characteristics in comparison to intensive systems: on-farm cycling of

243 nutrients and resources, the development of local varieties and breeds, high spatial and

244 temporal structural diversity, use of local pollination and pest control services, and

245 effective exploitation of local environmental heterogeneity (Altieri 2004). While

246 modern, intensive farming methods are usually better than traditional methods at

247 maximising production, they do so by increasingly using vast off-farm resources, such

248 as inorganic fertilisers, new crop breeds and specialised machinery (Woods and others

249 2010). In comparison with these intensive approaches, traditional farming in many

250 countries has been shown to have many environmental and societal benefits, including: 
enhancement of soil carbon sequestration (Ardo and Olsson 2004) and nutrient cycling

252 (Badalucco and others 2010), reduction of soil erosion (He and others 2007), more efficient water use (Prasad and others 2004), and maintenance of crop genetic diversity (Pujol and others 2004; Jarvis and others 2008), as well as providing resources for endangered species (Blanco and others 2008; Olea and Mateo-Tomas 2009). Continuation of traditional farming is one matter (Altieri 2004), but it is probably not possible or desirable to "turn back the clock" in areas of more intensive farming. Wholesale reversion to earlier agricultural methods would reduce food production massively; for example the current UK wheat yield per hectare is more than threefold that realised in 1945 (UK National Ecosystem Assessment 2011). Furthermore, certain traditional methods, such as swidden agriculture, may sometimes

262 be damaging to biodiversity and to soil and water resources (Ziegler and others 2010). It is therefore more appropriate to learn lessons from traditional approaches which can be applied to modern agricultural systems. Perhaps the most important idea to borrow is to increase within- and between-farm diversity in terms of crops, cropping systems and land use. Such structural diversity at a variety of scales can reduce vulnerability of crop yield to between-year climatic variability (Reidsma and Ewert 2008), as well as increase biodiversity and associated ecosystem services (Benton and others 2003; Tscharntke and others 2005). Local reversions to traditional management approaches are being implemented, for example through the European agri-environment schemes. Options

271 within these include: a return to traditional livestock grazing rates and/or seasons, which

272 can help weed control (Pywell and others 2010) and maintenance of plant and animal

273 diversity (Redpath and others 2010); replacement of inorganic fertilisers with farmyard

274 manure, with positive impacts on soil organic matter (Hopkins and others 2011); or re-

275 creating traditional species-rich grasslands, in which increased plant diversity enhances 
276 forage production (Bullock and others 2007). More generally, there is global interest in

277 more traditional approaches to soil tillage involving reduced frequency and depth, 278 which can enhance soil nutrient cycling and stability, and pest control, while also

279 reducing energy use (Roger-Estrade and others 2010; Woods and others 2010).

281 Transformation of conventional agriculture into organic agriculture

282 There has been a considerable expansion of organic farmland area in the world (a three283 fold increase between 1999 and 2006), chiefly in the developed countries. The demand 284 for healthy and environmentally-friendly food and subsidies to producers of organic 285 food and fibre has favoured this process (Pimentel and others 2005). However, organic 286 farming remains a tiny fraction of the farming activity (Figure 1), comprising 4.1\% and $2870.42 \%$ of the total agricultural area in EU27+ and the USA in 2008, respectively 288 (FAOSTAT 2011).

289 The benefits of organic farming to the environment are well described, and 290 include less contamination by fertilizers, herbicides and pesticides, increases in 291 biodiversity (Bengtsson and others 2005; Hole and others 2005; Rundlof and others 292 2008; Aviron and others 2009; Danhart and others 2010; Gabriel and others 2010; Jose293 Maria and others 2010), enhancement of soil carbon sequestration and nutrients 294 (Kimble 2002; Pimentel and others 2005), enhancement of natural pest control 295 (Mccfadyen and others 2009; Crowder and others 2010), and conservation of the 296 genetic diversity of local varieties of domestic plants and animals (Jarvis and others 297 2008). Importantly, other than benefits related to the environment and human health, it 298 has been demonstrated that organic farming usually produces similar or higher 299 quantities of agricultural products (Pimentel and others 2005; Crowder and others 2010) 
and with higher market prices than conventional farming (Born 2004; Pimentel and

301 others 2005), which can make it extremely profitable (Delbridge and others 2011).

303 organic agriculture will be required to maximise benefits (Gabriel and others 2010).

304 Meta-analyses of the effects of organic farming on species diversity have shown

305 variable results among studies and taxa, with detrimental effects of organic farming in

306 16\% (Bengtsson and others 2005) or 8.1\% (Hole and others 2005) of the individual

307 studies. Bengtsson and others (2005) also found no significant effects of organic

308 farming on soil microbial activity or biomass. Organic farming uses three broad

309 management practices (prohibition/reduced use of chemical pesticides and inorganic

310 fertilisers, sympathetic management of non-cropped habitats, and preservation of mixed

311 farming) that are largely intrinsic (but not exclusive) to organic farming, and that are

312 particularly beneficial for farmland wildlife (Bengtsson and others 2005; Hole et al.

313 2005). Thus, the role of organic farming per se on enhancement of biodiversity and

314 ecosystem services is unclear. Positive effects of organic farming on species richness

315 might be expected in intensively managed agricultural landscapes, but not in small-scale

316 landscapes comprising many other biotopes as well as agricultural fields. Consequently,

317 measures to preserve and enhance biodiversity should be more landscape- and farm-

318 specific than is presently the case (Bengtsson and others 2005; Danhart and others 2010;

319 Gabriel and others 2010).

321 Transformation of simple crops and pastures into agroforestry systems

322 Agroforestry is the purposeful growing of trees/shrubs with crops or pasture. These 323 approaches offer opportunities in both tropical and temperate regions (Rigueiro324 Rodríguez and others 2009; Bergmeier and others 2010). Agroforestry can augment 
325 biodiversity and ecosystem services in agricultural landscapes, while also providing

326 income for rural livelihoods. It can be a management tool of buffer zones and biological 327 corridors to enhance landscape connectivity and landscape-level biodiversity 328 (Vandermeer and Perfecto 2007; Rigueiro-Rodríguez and others 2009; Lombard and 329 others 2010). Agroforestry represents an intermediate step between natural secondary 330 forests (Cramer and Hobbs 2007) and reclamation of severely degraded land (Koch and 331 Hobbs 2007) in terms of high vs. low provision of biodiversity and ecosystem services, state of degradation, and time and costs of forest restoration (Chazdon 2008). Agrosuccessional restoration schemes have been proposed, which include agroecological and agroforestry techniques as a step prior to forest restoration (Vieira and others 2009).

Restoring or creating specific elements to benefit wildlife and particular services

This type of intervention encompasses highly specific actions intended to benefit wildlife and particular services such as pollination and game production. These actions are so characterized because they occupy a tiny fraction of the agricultural land if any at all, meaning that they hardly compete for farmland use. Actions include: (1) strategic revegetation of property boundaries, field margins and track edges to create living fences (Noordijk and others 2010; Pereira and Rodríguez 2010; Poggio and others 2010); (2) planting isolated trees to take advantage of their disproportionate positive

344 value for biodiversity conservation and potential for seed dispersal (DeMars and others

345 2010; Fischer and others 2010); (3) creation of pollinator-friendly areas using plant 346 enrichment (Kohler and others 2008; Ricketts and others 2008; Carvalheiro and others 347 2010; Hagen and Kraemer 2010); (4) introduction of beetle banks, stone walls, stone 348 mounds and other strategic refuges for fauna (MacLeod and others 2004); (5) 349 introduction of perches and nest-boxes for birds (see example below); and (6) 
introduction or restoration of drinking troughs. (7) The reconstruction of rural architecture is specifically intended to restore and value cultural services. There will usually be scale effects on biodiversity and ecosystem services depending on how much land is affected by these actions. rodent control is an outstanding example of this type of wildlife-friendly farming. This project was motivated by periodic field vole Microtus arvalis outbreaks, which are often controlled using poisons that may damage wildlife and game. Common kestrel Falco tinnunculus and barn owl Tyto alba are rodent predators that have declining populations for a number of reasons, including lack of sites for nesting in open landscapes. Thus, more nesting sites (photo in Figure 2) should increase the populations of these two species and contribute to place their populations at the carrying capacities. To achieve this goal, an agricultural landscape in central Spain was seeded with nest boxes. We calculate that total rodent consumption could be as high as ca. $46,250 \mathrm{~kg} \mathrm{yr}^{-1}$ if full nest occupancy by both species were attained, a figure that is expected to contribute to rodent damage control and the maintenance of these birds of prey species.

\section{Land separation}

368 Land separation and land sharing are sometimes treated as alternatives (e.g. Phalan and others 2011). However, as different actions benefit different species and ecosystem services (Brussard and others 2010; Pilgrim and others 2010; Phalan and others 2011), a variety of approaches would likely be the most successful at enhancing biodiversity and

372 ecosystem services. Setting aside farmland to restore or create non-farm habitat rarely

373 happens as farmers tend to use and expand into all available land since this is usually 374 the most profitable choice in terms of direct use value (TEEB 2010). There are, though, 
some examples of habitat restoration at the expense of farmland, including both

376 terrestrial (see below) and wetland ecosystems (Thiere and others 2009; Moreno-Mateos

377 and others 2010). Two major contrasting approaches for terrestrial ecosystem

378 restoration in agricultural landscapes are: (1) passive restoration through secondary

379 succession following abandonment of agricultural land, e.g. cropland and pastures

380 where extensive livestock farming has been removed; and (2) active restoration, for example through addition of desired plant species. These approaches have been contrasted for a variety of ecosystem targets, including species-rich grassland (Pywell and others 2002) and heathland (Pywell and others 2011), but in the following we focus on forest restoration.

The estimated global deforestation rate of 13 million ha $\mathrm{yr}^{-1}$ over the last ten years has resulted in a net loss of forest area of 5.2 million ha $\mathrm{yr}^{-1}$ or $0.13 \% \mathrm{yr}^{-1}$ (FAO 2011). In the past, land abandonment and passive restoration led to the reforestation of a larger surface area than active restoration (4.1 million ha $\mathrm{yr}^{-1}$ vs. 3.6 million ha $\mathrm{yr}^{-1}$, respectively, in 2000-2005; FAO 2006). Over the period 2000-2010 these figures reversed and they are now 2.9 million ha $\mathrm{yr}^{-1}$ vs. 4.9 million ha $\mathrm{yr}^{-1}$, respectively (FAO 2011). Now $36 \%$ of forest area is primary forests, $57 \%$ is secondary forests and $7 \%$ is forest plantations (FAO 2010).

Passive restoration is cheap (although it may include opportunity costs) and

394 leads to a local vegetation type (Myers and Harms 2009). It is generally fast in 395 productive environments, but slow in low productivity environments as woody 396 vegetation establishment is limited (Rey Benayas and others 2008). The restoration capacity of woody ecosystems depends on the magnitude and duration of ecosystem modification, i.e., the "agricultural legacy" (Dwyer and others 2010). A key bottle-neck 
that hinders revegetation in vast agricultural landscapes is the lack of propagules due to

400 absence of mother trees and shrubs (García and others 2010).

Active forest restoration basically comprises the planting of trees and shrubs. It

is needed, for example, when abandoned land suffers continuing degradation, local

vegetation cover cannot be recovered and secondary succession has to be accelerated.

404 There are differences in the biodiversity and ecosystem services provided by passive vs.

405 active restoration, and there is much debate about the ecological benefits of tree 406 plantations. For instance, the mean increment of carbon in young secondary forests of

407 Costa Rica is $4.18 \mathrm{Mg} \mathrm{ha}^{-1} \mathrm{yr}^{-1}$ in the biomass (including below ground biomass) and

$4081.07 \mathrm{Mg} \mathrm{ha}^{-1} \mathrm{yr}^{-1}$ in the soil (Fonseca and others 2011a). These figures are higher in 409 plantations of the native tree species Vochysia guatemalensis (7.07 $\mathrm{Mg} \mathrm{ha}^{-1} \mathrm{yr}^{-1}$ in the 410 biomass and 1.66 $\mathrm{Mg} \mathrm{ha}^{-1} \mathrm{yr}^{-1}$ in the soil) and Hieronyma alchorneoides (5.26 Mg ha ${ }^{-1}$ $411 \mathrm{yr}^{-1}$ in the biomass and $1.27 \mathrm{Mg} \mathrm{ha}^{-1} \mathrm{yr}^{-1}$ in the soil) (Fonseca and others 2011b).

412 Plantations are thus better for sequestering carbon and for timber production than 413 secondary forests in this and many other case studies (e.g. Piao and others 2009; 414 Rautiainen and others 2010); however, they are less valuable for non-timber forest 415 products and biodiversity (Newton and Tejedor 2011).

$416 \quad$ Bremer and Farley (2010) analysed published data on plant species richness in 417 plantations and paired land uses, most often representative of pre-plantation land cover. 418 They found that plantations are most likely to contribute to biodiversity when 419 established on degraded lands rather than replacing natural ecosystems, and when 420 indigenous tree species are used rather than exotic species. Similarly, a meta-analysis of 421 faunal and floral species richness and abundance in timber plantations and pasture lands 422 on 36 sites across the world concluded that plantations support higher species richness 423 or abundance than pasture land only for particular taxonomic groups (i.e. herpetofauna), 
424 or specific landscape features (i.e. absence of remnant vegetation within pasture)

425 (Felton and others 2010). Zhang and others (2010) also found higher levels of plant 426 diversity,soil fertility and organic matter on land undergoing secondary succession than 427 on tree plantations in northwest China.

428 China's Grain to Green project and the afforestation of former agricultural land 429 in southern Europe are examples of trade-offs between different types of ecosystem 430 services and biodiversity. Under the former project, which has the intention to restore services and biodiversity (Tallis and others 2008), activities includes planting nonnative trees on agricultural land to decrease soil erosion. This has led to decreased native vegetation cover and increased water use, suggesting negative impacts on 434 biodiversity and water availability in arid areas (Cao and others 2009; Chen and others 435 2010). Cropland afforestations in southern Europe are mostly based on coniferous species such as Pinus halepensis and $P$. pinaster, although other species are used. The fast-growing plantations are certainly better for carbon sequestration rates than secondary succession of Mediterranean shrubland and woodland (Rey Benayas and others 2010a). However, these plantations may cause severe damage to open habitat

440 species, especially birds, by replacing high quality habitat and increasing risk of 441 predation (Reino and others 2010). Further, they have been shown to be suitable habitats for generalist forest birds but not for specialist forest birds, whereas secondary succession shrubland and woodland favour bird species that are of conservation concern

444 in Europe (Rey Benayas and others 2010a). Navarro-Cano and others (2010) showed 445 that pine litter from afforestations hinders the establishment of endemic plants in semiarid scrubby habitats of the Natura 2000 Network. 
449 The agriculture and conservation paradox creates a dilemma in woodland restoration

450 projects, which can only be resolved by considering the relative values of biodiversity

451 and ecosystem services associated with woodland vs. agricultural ecosystems (Rey

452 Benayas and others 2008). The reconstruction of vegetation in a landscape ("where and

453 when to revegetate?”) is an issue that deserves to become a research priority (Munro

454 and others 2009; Thompson and others 2009). Rey Benayas and others (2008) suggested

455 a new concept for designing restoration of forest ecosystems on agricultural land, which

456 uses small-scale active restoration as a driver for passive restoration over much larger

457 areas. Establishment of "woodland islets" is an approach to designing restoration of

458 woodlands in extensive agricultural landscapes where no remnants of native natural

459 vegetation exist. It involves planting a number of small, densely-planted, and sparse

460 blocks of native shrubs and trees within agricultural land that together occupy a tiny

461 fraction of the area $(<1 \%)$ of target land to be restored. This approach, later called

462 “applied nucleation” by Corbin and Holl (2012), allows direction of secondary

463 succession by establishing small colonisation foci, while using a fraction of the

464 resources required for large-scale reforestation. Woodland patches provide sources of

465 seed and dispersing animals that can colonize adjacent habitats (Cole and others 2010).

466 If the surrounding land is abandoned, colonists from the islets could accelerate

467 woodland development because dispersal of many woodland organisms will continue

468 over many years. The landscape emphasis on a planned planting of islets maximises

469 benefits to biodiversity and the potential of allowing the islets to trigger larger-scale

470 reforestation if the surrounding land is abandoned. The islets should be planted with a

471 variety of native shrub and tree species including those identified as nurse species to

472 take advantage of facilitation processes (Butterfield and others 2010; Cuesta and others

473 2010). 
Vegetation dynamics in complex landscapes depend on interactions among

475 environmental heterogeneity, disturbance, habitat fragmentation, and seed dispersal 476 processes. For instance, European jays (Garrulus glandarius) are major long-distance 477 (500-600 m) dispersers of acorns in Mediterranean landscapes (Gómez 2003). The 478 introduction of woodland islets planted with oaks at a distance of one $\mathrm{km}$ from each 479 other in a deforested agricultural landscape could facilitate acorn arrival to all points in 480 a given landscape (Figure 3). In heterogeneous Mediterranean landscapes, jays disperse 481 acorns preferentially towards recently abandoned agricultural fields, forest tracks and 482 pine reforestations, whilst they usually avoid dense shrubland, grasslands and mature 483 holm oak forests (Gómez 2003; Pons and Pausas 2007). Purves and others (2007) found that jay-mediated directed dispersal increases regional abundance of three native oak 485 species. Montoya and others (2008) indicated that animal-dispersed tree species were 486 less vulnerable to forest loss than wind-dispersed species, i.e. plant-animal interactions 487 help prevent the collapse of forest communities suffering habitat destruction. Accordingly, Ozinga and others (2009) concluded that the 'colonization deficit' of plant species due to a degraded dispersal infrastructure is equally important in explaining 490 plant diversity losses as habitat quality, and called for new measures to restore the 491 dispersal infrastructure across entire regions.

The woodland islets approach maintains flexibility of land use, which is critical in agricultural landscapes where land use is subject to a number of fluctuating policy 494 and economic drivers. It provides a means of reconciling competing land for agriculture, 495 conservation and woodland restoration at the landscape scale. This could increase the 496 economic feasibility of large-scale restoration projects and facilitate the involvement of 497 local human communities in the restoration process. The woodland islets idea has 498 similarities to other approaches involving planting small areas of trees on farms, such as 
tree clumps, woodlots, hedges, living fences, or shelterbelts and agro-forestry systems

500 (see above). These practices provide ecological benefits as well as supporting farm

501 production, whereas the woodland islets approach is primarily designed to provide

502 additional ecological benefits other than agricultural production (Rey Benayas and 503 others 2008).

504

RESTORATION OF AGRICULTURAL LANDSCAPES IN THE

506

507

508

509

510

511

512

513

514

515

516

517

518

519

520

521

522

523

\section{REAL WORLD}

The response of human society to halt declining biodiversity indicators and environmental degradation shows positive trends, but so far it has been insufficient to achieve such goals (Butchart and others 2010; Rands and others 2010). Production science and conservation biology have long focused on providing the knowledge base for intensive food production and biodiversity conservation, respectively, but the largely separate development of these fields is counterproductive (Brussard and others 2010). Developing and strengthening a more interactive relationship between the science of restoration ecology and agroecology and the practice of ecological restoration and conservation farming has been a central but elusive goal (Gonzalo-Turpin and others 2008, Cabin and others 2010). Further research is needed to produce more sustainable socio-ecosystems (Turner 2010), but that will not be enough to reach the ultimate objective. Restoration actions that enhance both biodiversity and ecosystem services on agricultural land are necessary to reverse the world's declining biodiversity and ecosystem services (Bullock and others 2011; Foley et al. 2011).

The adoption of environmentally-friendly practices for agriculture, however, is not solely based on services and values that society as a whole obtains from such functions, as individual farmers are ultimately the agents who decide how much natural 
524 capital to conserve and utilize based on their own objectives and needs, including the

525 social, economic (e.g., markets and policies), and environmental conditions in which 526 they operate (Jackson and others 2007). One key problem is that the private and social

527 values of environmentally-friendly farming differ and the markets and policies often do 528 not align such values properly (Pascual and Perrings, 2007). The privately perceived 529 value is reflected by the financial benefits arising from positive effects on productivity 530 and/or the savings generated when wildlife-friendly farming substitutes for costs of synthetic inputs, e.g., pesticides. The total or social economic value of environmentallyfriendly farming includes the value of the ecological services that it provides to others than farmers, e.g., through environmental quality, recreation, and aesthetic values.

534 Generally, individual farmers react to the private use-value of biodiversity and 535 ecosystem services assigned in the marketplace and thus typically ignore the 'external' benefits of conservation that accrue to wider society (Jackson and others 2007).

Key issues for widespread ecological restoration on agricultural land are

538 financial support and education to promote farmer and public awareness and training.

539 Land owners must be explicitly rewarded for restoration actions occurring at their

540 properties in a time when society demands from agricultural land much more than food,

541 fiber and fuel production (Klimek and others 2008). The privately financial benefits

542 arising from environmental-friendly agricultural practices explained above may actually

543 be a reward to land owners, but may be insufficient. To reward the total or social value,

544 tax deduction for land owners who implement measures to restore agricultural land and

545 donations to not-for-profit organizations that run restoration projects (most restoration 546 projects are actually run by NGOs), payment for environmental services and direct

547 financing measures related to restoration activities should be put into operation widely.

548 These support mechanisms are very variable across countries. Incentives related to tax 
549 deduction are more generous in the US ( $>90 \%$ of the donated amount of money) than in

550 Europe (e.g. 60-65\% in France and 25\% in Spain), and non-existent in many countries.

A potentially major approach to funding restorations is through Payment for

552 Ecosystem Services (PES), which is designed to compensate for actions that secure

553 services such as water purification, flood mitigation, or carbon sequestration (Jack and

554 others 2008). In recent years many hundreds of PES have been established worldwide

555 for environmental management (Farley and others 2010) and some have focused on

556 restoration, such as China's Grain to Green Program (Tallis and others 2008) and

557 Madagascar's Mantadia PES (Wendland and others 2010). Globally, direct financing

558 measures to support restoration projects have mostly to do with afforestation measures

559 (Bigsby 2009). In the EU, major policy measures to support the provision of

560 environmental public goods through agriculture are: (1) agri-environment measures (a budget of $€ 34$ billion including co-financing for 2007-2013, 34 million ha affected); (2) (a budget of $€ 6.1$ billion $\mathrm{yr}^{-1}$ for the period 2007-2013, with ca. 15 million ha under agricultural management); (4) Good Agricultural and Environmental Condition standards that specify actions beyond existing legislation focusing specifically on maintaining landscape features, habitats, soil functionality or water quality; (5) aid schemes for forestry measures in agriculture (ca. 1 million ha have been afforested to date); and (6) structural funds (projects under the heading 'Preservation of the environment in connection with land ... and landscape conservation').

570 Environmental degradation will continue to increase while the world's citizens

571 do not acknowledge the value of biodiversity and ecosystem services for human well-

572 being. For that shift in understanding to happen, it is necessary to have widespread

573 education at various levels to promote public awareness (Hall and Bauer-Armstrong 
574 2010). Professional training is necessary as well to build up the capabilities to reconcile

575 agricultural production and the conservation or enhancement of biodiversity and other 576 ecosystem services (Rey Benayas and others 2010b). Farmers obviously play a key role, 577 and progress is required in engaging farmers better with the concept and methods of 578 land management for purposes other than production (Burton and others 2008).

\section{CONCLUSIONS}

581 We conclude that, although agriculture is a major cause of environmental degradation, 582 ecological restoration on agricultural land offers opportunities to reconcile agricultural production with enhancement of biodiversity and ecosystem services other than production. Restoration by land sharing through environmentally-friendly farming has the potential to enhance agricultural production, other ecosystem services and biodiversity at both the farmed field and landscape scale; however, restoration by land separation would provide these triple benefits only at the landscape scale as this restoration type is at the expense of field-level agricultural production. Beyond scientific and technical research, an increase in such restoration projects is needed if we want to halt environmental degradation and biodiversity loss and meet the CBD goals. We need widespread expansion of agricultural management based on ecological

592 knowledge: biodiversity-based agricultural practices, organic farming, agroforestry systems, learning from traditional practices, highly specific actions to benefit wildlife and particular ecosystem services, and converting some agricultural land into natural ecosystems such as forests. Financial support, public awareness, education and training, particularly of farmers, are necessary to accomplish such objectives. Restoration actions

597 can act as an engine of economy and a source of green employment, so policymakers have an extra incentive to restore degraded farmland habitat. 
601 Projects from the Spanish Ministry of Science and Education (CGL2010-18312), the

602 Government of Madrid (S2009AMB-1783, REMEDINAL) and the UK RELU

603 FarmCAT project (RES-227-25-0010) are currently providing financial support for this

604 body of research. We are indebted to Liliana Tovar for her input with table and figure

605 building. Two anonymous reviewers and Ann Kinzig provided valuable comments to

606 previous versions of this manuscript.

\section{References}

608 Altieri MA. 2004. Linking ecologists and traditional farmers in the search for 609 sustainable agriculture. Front Ecol Environ 2:35-42.

610 Ardo J, Olsson L. 2004. Soil carbon sequestration in traditional farming in Sudanese dry

611 lands. Environ Manage 33:S318-S329.

612 Aviron S, Nitsch H, Jeanneret P, Buholzer S, Luka H, Pfiffner L, Pozzi S, Schüpbach B,

613 Walter T, Herzog, F. 2009. Ecological cross compliance promotes farmland 614 biodiversity in Switzerland. Fron Ecol Environ 7:247-252.

615 Badalucco L, Rao M, Colombo C, Palumbo G, Laudicina VA, Gianfreda L. 2010.

616 Reversing agriculture from intensive to sustainable improves soil quality in a semiarid 617 South Italian soil. Biol Fertility Soil 46:481-489.

618 Bennett EM, Peterson GD, Gordon L. 2009. Understanding relationships among 619 multiple ecosystem services. Ecol Lett 12:1394-1404.

620 Benton TG, Vickery JA, Wilson JD. 2003. Farmland biodiversity: is habitat 621 heterogeneity the key? Trends Ecol Evol 18:182-188.

622 Bergmeier E, Petermann J, Schroder E. 2010. Geobotanical survey of wood-pasture 623 habitats in Europe: diversity, threats and conservation. Biodiversity Conserv 624 19:2995-3014.

625 Bianchi FJJA, Booij CJH, Tscharntke T. 2006. Sustainable pest regulation in 626 agricultural landscapes: a review on landscape composition, biodiversity and natural 627 pest control. Proc Roy Soc Biol Sci 273:1715-1727. 
Bigsby H. 2009. Carbon banking: Creating flexibility for forest owners. For Ecol Manage 257:378-383.

BirdLife International. 2008. State of the world's birds: indicators for our changing world. BirdLife International, Cambridge.

Blanco G, Tella JL, Torre I, 1998. Traditional farming and key foraging habitats for chough Pyrrhocorax pyrrhocorax conservation in a Spanish pseudosteppe landscape. J Appl Ecol 35:232-239.

Born H. 2004. Organic Marketing Resources [on line]. URL: http://attra.ncat.org/attrapub/markres.html.

Bremer LL, Farley KA. 2010. Does plantation forestry restore biodiversity or create green deserts? A synthesis of the effects of land-use transitions on plant species richness. Biodiversity Conserv 19:3893-3915.

Brussaard L, Caron P, Campbell B, Lipper L, Mainka S, Rabbinge R, Babin D, Pulleman M. 2010. Reconciling biodiversity conservation and food security: scientific challenges for a new agriculture. Current Opinion Environ Sustain 2:1-9.

Bullock JM, Pywell RF, Walker KJ. 2007. Long-term enhancement of agricultural production by restoration of biodiversity. J Appl Ecol 44:6-12.

Bullock JM, Aronson J, Newton AC, Pywell RF, Rey-Benayas JM. 2011. Restoration of ecosystem services and biodiversity: conflicts and opportunities. Trends Ecol Evol 26:541-549.

Burton R, Kuczera C, Schwarzet G. 2008. Exploring farmers’ cultural resistance to voluntary agri-environmental schemes. Sociologia Ruralis 48:16-37.

Butchart SHM and others (45 authors). 2010. Global biodiversity: indicators of recent declines. Science 328:1164-1168.

Butterfield BJ, Betancourt JL, Turner RM, Briggs JM. 2010. Facilitation drives 65 years

654 Cabin RJ, Clewell A, Ingram M, McDonald T, Temperton V. 2010. Bridging restoration science and practice: results and analysis of a survey from the 2009 society for ecological restoration international meeting. Restor Ecol 18:783-788.

Cao SX, Chen L, Yu XX. 2009. Impact of China's Grain for Green Project on the landscape of vulnerable arid and semi-arid agricultural regions: a case study in northern Shaanxi Province. J Appl Ecol 46:536-543. 
660 Carvalheiro LG, Seymour CL, Veldtman R, Nicolson SW. 2010. Pollination services 661 decline with distance from natural habitat even in biodiversity-rich areas. J Appl Ecol $662 \quad 47: 810-820$.

663 Cayuela, L, Rey Benayas JM, Echeverría C. 2006. Clearance and fragmentation of 664 tropical montane forests in the Highlands of Chiapas, Mexico (1975-2000). For Ecol 665 Manage 226:208-218.

666 Chazdon RL. 2008. Beyond deforestation: restoring forests and ecosystem services on 667 degraded lands. Science 320:1458-1460.

668 Chabi-Olaye A, Nolte C, Schulthess F, Borgemeister C. 2005. Effects of grain legumes 669 and cover crops on maize yield and plant damage by Busseola fusca (Fuller) 670 (Lepidoptera: Noctuidae) in the humid forest of southern Cameroon. Agric Ecosyst 671 Environ 108:17-28.

672 Chen LD, Wang JP, Wei W, Fu BJ, Wu DP. 2010. Effects of landscape restoration on 673 soil water storage and water use in the Loess Plateau Region, China. For Ecol 674 Manage 259:1291-1298.

675 Cole RJ, Holl KD, Zahawi RA. 2010. Seed rain under tree islands planted to restore 676 degraded lands in a tropical agricultural landscape. Ecol Appl 20:1255-1269.

677 Cooper HD, Spillane C, Hodgkin T. (Eds.). 2001. Broadening the genetic base of crop 678 production. CABI Publishing, New York, USA.

679 Corbin JD, Holl KD. 2012. Applied nucleation as a forest restoration strategy. For Ecol $680 \quad$ Manage 265: 37-46.

681 Cramer VA, Hobbs RJ, Eds. 2007. Old Fields: dynamics and restoration of abandoned 682 farmland. Island Press, Washington.

683 Crowder DW, Northfield TD, Strand MR, Snyder WE. 2010. Organic agriculture 684 promotes evenness and natural pest control. Nature 466:109-U123.

685 Cuesta B, Villar-Salvador P, Puértolas J, Rey Benayas JM, Michalet R. 2010. 686 Facilitation of Quercus ilex in Mediterranean shrubland is explained by both direct 687 and indirect interactions mediated by herbs. J Ecol 98:687-696.

688 Danhardt J, Green M, Lindstrom A, Rundlof M, Smith HG. 2010. Farmland as stopover 689 habitat for migrating birds - effects of organic farming and landscape structure. 690 Oikos 119:1114-1125.

691 Delbridge TA, Coulter JA, King RP, Sheaffer CC, Wyse DL. 2011. Economic 692 performance of long-term organic and conventional cropping systems in Minnesota. 693 Agron. J. 103:1372-1382. 
694 DeMars CA, Rosenberg DK, Fontaine JB. 2010. Multi-scale factors affecting bird use 695 of isolated remnant oak trees in agro-ecosystems. Biol Conserv 143:1485-1492.

696 Dicke M, Loon JAV, Jon PWD. 2004. Ecogenomics benefits community ecology. 697 Science 305:618-619.

698 Dornelas M, Moonen AC, Magurran AE, Barberi P. 2009. Species abundance 699 distributions reveal environmental heterogeneity in modified landscapes. J Appl Ecol $700 \quad 46: 666-672$.

701 Doxa A, Bas Y, Paracchini ML, Pointereau P, Terres JM, Jiguet F. 2010. Low-intensity 702 703 agriculture increases farmland bird abundances in France. J Appl Ecol 47:13481356.

704

Dwyer JM, Fensham RJ, Buckley YM. 2010. Agricultural legacy, climate, and soil 705 influence the restoration and carbon potential of woody regrowth in Australia. Ecol Appl 20:1838-1850.

Ellis EC, Ramankutty N. 2008. Putting people in the map: anthropogenic biomes of the world. Fron Ecol Environ 6:439-447.

709

Elmqvist T, Folke C, Nyström M, Peterson G, Bengtsson J, Walker B, et al. 2003. Response diversity, ecosystem change, and resilience. Front Ecol Environ 1:488494.

European Bird Census Council. 2010. Pan-European common bird monitoring scheme

714 FAO. 2006. The Global Forest Resources Assessment 2005 [on line]. FAO, Rome (URL: http://www.fao.org/forestry).

716 FAO. 2009. The resource outlook to 2050: By how much do land, water and crop yields

717 need to increase by 2050? [on line]. FAO, Rome (URL:

718 ftp://ftp.fao.org/docrep/fao/012/ak971e/ak971e00.pdf).

719 FAO. 2010. The Global Forest Resources Assessment 2010 [on line]. FAO, Rome 720 (URL: http://www.fao.org/docrep/013/i2000s/i2000s.pdf).

721 FAO. 2011. State of the World's Forests 2011 [on line]. FAO, Rome (URL: 722 http://www.fao.org/docrep/013/i2000e/i2000e00.htm).

723 FAOSTAT 2011. FAO Statistics Division (URL: , 16 February 2011).

724 Farley J, Aquino A, Daniels A, Moulaert A, Lee D, Krause A. 2010. Global 725 mechanisms for sustaining and enhancing PES schemes. Ecol Econ 69:2075-2084. 
Felton A, Knight E, Wood J, Zammit C, Lindenmayer D. 2010. A meta-analysis of fauna and flora species richness and abundance in plantations and pasture lands Biol Conserv 143:545-554.

Fischer J, Brosi B, Daily GC, Ehrlich PR, Goldman R, Goldstein J, Lindenmayer DB, Manning AD, Mooney HA, Pejchar L, Ranganathan J, Tallis H. 2008. Should agricultural policies encourage land sparing or wildlife-friendly farming? Fron Ecol Environ 6:382-387.

Fischer J, Stott J, Law BS. 2010. The disproportionate value of scattered trees. Biol Conserv 143:1564-1567.

Flynn DFB, Gogol-Prokurat M, Nogeire T, Molinari N, Richers BT, Lin BB, Simpson N, Mayfield MM, DeClerck F. 2009. Loss of functional diversity under land use intensification across multiple taxa. Ecol Lett 12:22-33.

Foley JA, DeFries R, Asner GP, Barford C, Bonan G, Carpenter SR, Chapin FS, Coe MT, Daily GC, Gibbs HK, Helkowski JH, Holloway T, Howard EA, Kucharik CJ, Monfreda C, Patz JA, Prentice IC, Ramankutty N., Snyder PK. 2005. Global consequences of land use. Science 309:570-574.

Foley JA, Ramankutty N, Brauman KA, Cassidy ES, Gerber JS, Johnston M, Mueller ND, O’Connell C, Ray DK, West PC, Balzer CB, Bennett LM, Carpenter SR, Hill J, Monfreda C, Polasky S, Rockstrom J, Sheehan J, Siebert S, Tilman D, Zaks DPM. 2012. Solutions for a cultivated planet. Nature 478:337-342.

Fonseca W, Rey Benayas JM, Alice F. 2011. Carbon accumulation in the biomass and soil of different aged secondary forests in the humid tropics of Costa Rica. For Ecol Manage 262:1400-1408.

Fonseca W, Alice F, Rey Benayas JM. 2011. Carbon accumulation in aboveground and belowground biomass and soil of different age native forest plantations in the humid tropical lowlands of Costa Rica. New Forests, DOI 10.1007/s11056-011-9273-9.

Gabriel D, Sait SM, Hodgson JA, Schmutz U, Kunin WE, Benton TG. 2010. Scale matters: the impact of organic farming on biodiversity at different spatial scales. Ecol Lett 13:858-869.

Garcia D, Zamora R, Amico G. 2010. Birds as suppliers of seed dispersal in temperate ecosystems: conservation guidelines from real-world landscapes. Conserv Biol 24:1070-1079.

Geiger F, Bengtsson J, Berendse F,_Weisser WW, Emmerson M, Morales MB, Ceryngier P, Liira J, Tscharntke T, Winqvist C, Eggers S, Bommarco R, Paärt T, 
Bretagnolle V, Plantegenest M, Clement LW, Dennis C, Palmer C, Oñate JJ, Guerrero I, Hawro V, Aavik T, Thies C, Flohre A, Hänke S, Fischer C, Goedhart PW, Inchausti P. 2010. Persistent negative effects of pesticides on biodiversity and biological control potential on European farmland. Basic Appl Ecol 11:97-105.

Gómez JM. 2003. Spatial patterns in long-distance dispersal of Quercus ilex acorns by jays in a heterogeneous landscape. Ecography 26:573-584.

Gonzalo-Turpin H, Couix N, Hazard L. 2008. Rethinking partnerships with the aim of producing knowledge with practical relevance: a case study in the field of ecological restoration. Ecol Soc 13:53-53.

Grau HR, Aide M. 2008. Globalization and land-use Transitions in Latin America. Ecol Soc 13:16-16.

Green RE, Cornell SJ, Scharlemann JPW, Balmford A. 2005. Farming and the fate of wild nature. Science 307:550-555.

Hagen M, Kraemer, M. 2010. Agricultural surroundings support flower-visitor networks in an Afrotropical rain forest. Biol Conserv 143:1654-1663.

Hall R., Bauer-Armstrong C. 2010. Earth partnership for schools: ecological restoration in schools and communities. Ecol Restor 28:208-212.

He XB, Xu YB, Zhang XB. 2007. Traditional farming system for soil conservation on slope farmland in southwestern China. Soil Tillage Res 94:193-200.

Hockley NJ, Jones, JPG, Gibbons J. 2008 Technological progress must accelerate to reduce ecological footprint overshoot. Fron Ecol Environ 6:122-123.

Hodgson JA, Kunin WE, Thomas CD, Benton TG, Gabriel D. 2010. Comparing organic farming and land sparing: optimizing yield and butterfly populations at a landscape scale. Ecol Lett 13:1358-1367.

Hole DG, Perkins AJ, Wilson JD, Alexander IH, Grice PV, Evans AD. 2005. Does organic farming benefit biodiversity? Biol Conserv 122:113-130.

Hopkins DW, Waite IS, O'Donnell AG. 2011. Microbial biomass, organic matter mineralization and nitrogen in soils from long-term experimental grassland plots (Palace Leas meadow hay plots, UK). Eur J Soil Sci 62:95-104.

IPCC. 2007. Climate Change 2007. Synthesis Report. IPCC, Geneve [on line]. (URL: http://www.ipcc.ch/publications_and_data/publications_ipcc_fourth_assessment_rep ort_synthesis_report.htm). 
Jack BK, Kousky C, Sims KRE. 2008. Designing payments for ecosystem services: Lessons from previous experience with incentive-based mechanisms. Proc Natl Acad Sci USA 105:9465-9470.

Jackson LE, Pascual U, Hodgkin T. 2007. Utilizing and conserving agrobiodiversity in agricultural landscapes. Agric Ecosyst Environ 121:196-210.

Jarvis DI, Brown AHD, Cuong PH, Collado-Panduro L, Latournerie-Moreno L, Gyawali S, Tanto T, Sawadogo M, Mar I, Sadiki M, Hue NTN, Arias-Reyes L, Balma D, Bajracharya J, Castillo F, Rijal D, Belqadi L, Ranag R, Saidi S, Ouedraogo J, Zangre R, Rhrib K, Chavez JL, Schoen DJ, Sthapit B, De Santis P, Fadda C, Hodgkin T. 2008. A global perspective of the richness and evenness of traditional crop-variety diversity maintained by farming communities. Proc Natl Acad Sci USA 105:5326-5331.

805

Jose-Maria L, Armengot L, Blanco-Moreno JM, Bassa M, Sans FX. 2010. Effects of agricultural intensification on plant diversity in Mediterranean dryland cereal fields. J Appl Ecol 47:832-840.

Kiers ET, Leakey RRB, Izac AM, Heinemann JA, Rosenthal E, Nathan D, Jiggins J. 2008. Ecology - Agriculture at a crossroads. Science 320:320-321.

Kimble JM. 2002. Agricultural practices and policies for carbon sequestration in soil. CRC Press, Tampa.

Kleijn D, Baquero RA, Clough Y, Díaz M, Esteban J, Fernández F, Gabriel D, Herzog F, Holzschuh A, Jöhl R, Knop E, Kruess A, Marshall EJ, Steffan-Dewenter I, Tscharntke T, Verhulst J, West TM, Yela JL. 2006. Mixed biodiversity benefits of agro-environment schemes in five European countries. Ecol Lett 9:243-254.

Kleyer M, Biedermann R, Henle K, Obermaier E, Poethke HJ, Poschlod P, Schroder B, Settele J, Vetterlein D. 2007. Mosaic cycles in agricultural landscapes of Northwest Europe. Basic Appl Ecol 8:295-309.

Klimek S, Kemmermann AR, Steinmann HH, Freese J, Isselstein J. 2008. Rewarding farmers for delivering vascular plant diversity in managed grasslands: A transdisciplinary case-study approach. Biol Conserv 141:2888-2897.

Koch JM, Hobbs RJ. 2007. Synthesis: is Alcoa successfully restoring a jarrah forest 823 Kohler F, Vandenberghe C, Imstepf R, Gillet F. 2008. Restoration of threatened arable 824 weed communities in abandoned mountainous crop fields. Restor Ecol 19:62-69. 
Lindemann-Matthies P, Jung, X, Matthie D. 2010. The influence of plant diversity on people's perception and aesthetic appreciation of grassland vegetation. Biol Conserv 143:195-202.

828 Liu J, Dietz T, Carpenter SR, Alberti M, Folke C, Moran E, Pell AN, Deadman P, 829 Kratz T, Lubchenco J, Ostrom E, Ouyang Z, Provencher W, Redman CL, Schneider 830 SH, Taylor WW. 2007. Complexity of coupled human and natural systems. Science $831 \quad 317:$ 1513-1516.

832 Lombard AT, Cowling RM, Vlok JHJ, Fabricius C. 2010. Designing conservation 833 corridors in production landscapes: assessment methods, implementation issues, and 834 lessons learned. Ecol Soc 15:7-7.

835 Macfadyen S, Gibson R, Polaszek A, Morris RJ, Craze PG, Planque R, Symondson 836 WOC, Memmott J. 2009. Do differences in food web structure between organic and 837 conventional farms affect the ecosystem service of pest control? Ecol Lett 12:229838238.

839 MacLeod A, Wratten SD, Sotherton NW, Thomas MB. 2004. 'Beetle banks' as refuges 840 for beneficial arthropods in farmland: long-term changes in predator communities and habitat. Agric For Entomol 6:147-154.

McLauchlan K. 2006. 2006. The nature and longevity of agricultural impacts on soil carbon and nutrients: A review. Ecosystems 9:1364-1382.

McNeely JA, Scherr SJ. 2003. Ecoagriculture: Strategies to Feed the World and SaveWild Biodiversity. Island Press, Washington, DC, USA.

Millenium Ecosystem Assessment (Ed.). 2005. Ecosystems and Human-Well Being. Island Press, New York.

Montoya D, Zavala MA, Rodríguez MA, Purves DW. 2008. Animal versus wind dispersal and the robustness of tree species to deforestation. Science 320:1502-1504.

Moreno-Mateos D, Pedrocchi C, Comín F.A. 2010. Effects of wetland construction on water quality in a semi-arid catchment degraded by intensive agricultural use. Ecol Engin 36:631-639.

Mulitza S, Heslop D, Pittauerova D, Fischer HW, Meyer I, Stuut JB, Zabel M, Mollenhauer G, Collins JA, Kuhnert H, Schulz M. 2010. Increase in African dust flux at the onset of commercial agriculture in the Sahel region. Nature 466:226-228. areas: the development of structural complexity and floristic diversity. Ecol Appl 19:1197-2010. 
Myers JA, Harms KE. 2009. Seed arrival, ecological filters, and plant species richness: a meta-analysis. Ecol Lett 12:1250-1260.

Navarro-Cano JA, Barbera GG, Castillo VM. 2010. Pine litter from afforestations hinders the establishment of endemic plants in semiarid scrubby habitats of Natura 2000 Network. Restor Ecol 18:165-169.

Newton, A.C. \& Tejedor, N. (eds.). 2011. Principles and Practice of Forest Landscape Restoration: Case studies from the drylands of Latin America. Gland, Switzerland: IUCN.

Noordijk J, Musters CJM, van Dijk J, de Snoo GR. 2010. Invertebrates in field margins: taxonomic group diversity and functional group abundance in relation to age. Biodiversity Conserv 19:3255-3268.

Normile D. 2010. U.N. Biodiversity Summit Yields Welcome and Unexpected Progress. Science 330:742-743.

Olea PP, Mateo-Tomas P. 2009. The role of traditional farming practices in ecosystem conservation: The case of transhumance and vultures. Biol Conserv 142:1844-1853.

Oliver T, Roy DB, Hill JK, Brereton T, Thomas, CD. 2010. Heterogeneous landscapes promote population stability. Ecol Lett 13:473-484.

Ostrom E. 2009. A general framework for analyzing sustainability of social-ecological systems. Science 325:419-422.

Ozinga WA, Romermann C, Bekker RM, Prinzing A, Tamis WLM, Schaminee JHJ, Hennekens SM, Thompson K, Poschlod P, Kleyer M, Bakker JP, van Groenendael JM. 2009. Dispersal failure contributes to plant losses in NW Europe. Ecol Lett 12:66-74.

Pereira M, Rodriguez A. 2010. Conservation value of linear woody remnants for two forest carnivores in a Mediterranean agricultural landscape. J Appl Ecol 47:611-620.

Pereira HM, Leadley PW, Proença V, Alkemade R, Scharlemann JPW, FernandezManjarrés JF, Araújo MB, Balvanera P, Biggs R, Cheung WWL, Chini L, Cooper HD, Gilman EL, Guénette S, Hurtt GC, Huntington HP, Mace GM, Oberdorff T, Revenga C, Rodrigues P, Acholes RJ, Sumaila UR, Walpole M. 2010. Scenarios for Global Biodiversity in the 21st Century. Science 330:1496-1501.

Phalan B, Onial M, Balmford A, Green RE. 2011. Reconciling food production and biodiversity conservation: land sharing and land sparing compared. Science 333:1289-1291. 
892 Piao SL, Fang JY, Ciais P, Peylin P, Huang Y, Sitch S, Wang T. 2009. The carbon 893 balance of terrestrial ecosystems in China. Nature 458:1009-U82.

894 Pilgrim ES, Macleod CJA, Blackwell MSA, Bol R, Hogan DV, Chadwick DR, 895 Cardenas L, Misselbrook TH, Haygarth PM, Brazier RE, Hobbs P, Hodgson C, 896 Jarvis S, Dungait J, Murray PJ, Firbank LG, Donald LS. 2010. Interactions among 897 agricultural production and other ecosystem services delivered from European 898 temperate grassland systems. Advances Agron:117-154. Academic Press.

899 Pimentel D, Hepperly P, Hanson J, Douds D, Seidel R. 2005. Environmental, energetic, 900 and economic comparisons of organic and conventional farming systems. BioScience $901 \quad 55: 573-582$.

902 Poggio SL, Chaneton EJ, Ghersa CM. 2010. Landscape complexity differentially affects 903 alpha, beta, and gamma diversity of plants occurring in fencerows and crop fields. 904 Biol Conserv 143:2477-2486.

905 Pons J, Pausas JG. 2007. Acorn dispersal estimated by radio-tracking. Oecologia $906 \quad$ 153:903-911.

907 Potts SG, Biesmeijer JC, Kremen C, Neumann P, Schweiger O, Kunin WE. 2010. 908 Global pollinator declines: trends, impacts and drivers. Trends Ecol Evol 25:345909353

910 Prasad R, Mertia RS, Narain P. 2004. Khadin cultivation: a traditional runoff farming 911 system in Indian Desert needs sustainable management. J Arid Environ 58:87-96.

912 Pujol B, David P, McKey D. 2005. Microevolution in agricultural environments: how a 913 traditional Amerindian farming practice favours heterozygosity in cassava (Manihot 914 esculenta Crantz, Euphorbiaceae). Ecol Lett 8:138-147.

915 Purves D, Zavala MA, Oglel K, Prieto F, Rey Benayas JM. 2007. Coupling 916 environmental forcing, metapopulation dynamics, and dispersal of Quercus species 917 in central Spain. Ecol Mon 77:77-97.

918 Putz FE, Redford KH, 2009. Dangers of carbon-based conservation. Global Environ 919 Chang 19:400-401.

920 Pywell RF, Bullock JM, Hopkins A, Walker KJ, Sparks TH, Burke MJW, Hayes MJ, 921 Tallowin JB, Walker KJ, Meek WR, Carvell C., Warman LA. 2010. Minimizing 922 environmental impacts of grassland weed management: can Cirsium arvense be 923 controlled without herbicides? Grass Forage Sci 65:159-174. 
924 Pywell RF, Bullock JM, Hopkins A, Walker KJ, Sparks TH, Burke MJW, Peel S. 2002.

925 Restoration of species-rich grassland on arable land: assessing the limiting processes $926 \quad$ using a multi-site experiment. J Appl Ecol 39:294-309.

927 Pywell RF, Meek WR, Webb NR, Putwain PD, Bullock JM. 2011. Long-term heathland 928 restoration on former grassland: The results of a 17-year experiment. Biol Conserv In 929 Press.

930 Rands MRW, Adams WM, Bennun L, Butchart SHM, Clements A, Coomes D, 931 Entwistle A, Hodge I, Kapos V, Scharlemann JPW, Sutherland WJ, Vira B. 2010. 932 Biodiversity Conservation: Challenges Beyond 2010. Science 329:1298-1303.

933 Ranganathan J, K, Raudsepp-Hearne C, Lucas N, Irwin F, Zurek M, Ash N, West P. 934 2008. Ecosystem services: a guide for decision makers [on line]. World Resources $935 \quad$ Institute (URL:

936 http://pdf.wri.org/ecosystem_services_guide_for_decisionmakers.pdf).

937 Rautiainen A, Saikk L, Kaupp PE. 2010. Carbon gains and recovery from degradation 938 of forest biomass in European Union during 1990-2005. For Ecol Manage 259:12329391238.

940 Redpath N, Osgathorpe LM, Park K, Goulson D. 2010. Crofting and bumblebee 941 conservation: The impact of land management practices on bumblebee populations in 942 northwest Scotland. Biol Conserv 143:492-500.

943 Reidsma P, Ewert F. 2008. Regional farm diversity can reduce vulnerability of food $944 \quad$ production to climate change. Ecol Soc 13:38.

945 Reino L, Porto M, Morgado R, Carvalho F, Mira A, Beja P. 2010. Does afforestation 946 increase bird nest predation risk in surrounding farmland? For Ecol Manage 260: $947 \quad$ 1359-1366.

948 Rey Benayas JM, Martins A, Nicolau JM, Schulz J. 2007. Abandonment of agricultural 949 land: an overview of drivrs and consequences. Perspec Agric Vet Sci Nutr Nat Res $950 \quad 2: 057$.

951 Rey Benayas JM, Bullock JM, Newton AC. 2008. Creating woodland islets to reconcile 952 ecological restoration, conservation, and agricultural land use. Fron Ecol Environ $9536: 329-336$.

954 Rey Benayas JM, Newton AC, Diaz A, Bullock JM. 2009. Enhancement of biodiversity 955 and ecosystem services by ecological restoration: a meta-analysis. Science 956 325:1121-1124. 
Rey Benayas JM, Galván I, Carrascal LM. 2010a. Differential effects of vegetation

958

959

960

961

962

963

964

965

966

967

968

969

970

971

972

973

974

975

976

977

978

979

980

981

982

983

984

985

986

987

988

989

990 restoration in Mediterranean abandoned cropland by secondary succession and pine plantations on bird assemblages. For Ecol Manage 260:87-95.

Rey Benayas JM, Escudero A, Martín Duque JF, Nicolau JM, Villar P, García de Jalón D, Balaguer L. 2010b. A multi-institutional Spanish Master in Ecosystem Restoration: vision and four-year experience. Ecol Restor 28:188-192.

Ricketts TH, Regetz J, Steffan-Dewenter I, Cunningham SA, Kremen C, Bogdanski A, Gemmill-Herren B, Greenleaf SS, Klein AM, Mayfield MM, Morandin LA, Ochieng A, Viana BF. 2008. Landscape effects on crop pollination services: are there general patterns? Ecol Lett 11:499-515.

Ridder B. 2008. Questioning the ecosystem services argument for biodiversity conservation. Biodiversity Conserv 17:781-790.

Rigueiro-Rodríguez A, McAdam J, Mosquera-Losada MR Eds. 2009. Agroforestry in Europe: Current Status and Future Prospects. Springer,

Roger-Estrade J, Anger C, Bertrand M, Richard G. 2010. Tillage and soil ecology: Partners for sustainable agriculture. Soil Tillage Res 111:33-40.

Rohr JR, Schotthoefer AM, Raffel TR, Carrick HJ, Halstead N, Hoverman JT, Johnson CM, Johnson LB, Lieske C, Piwoni MD, Schoff PK, Beasley VR. 2008. Agrochemicals increase trematode infections in a declining amphibian species Nature 455:1235-U50.

Rundlof M, Bengtsson J, Smith HG. 2008. Local and landscape effects of organic farming on butterfly species richness and abundance. J Appl Ecol 45:813-820.

Sitzia T, Semenzato P, Trentanovi G. 2010. Natural reforestation is changing spatial patterns of rural mountain and hill landscapes: A global overview. For Ecol Manage 259:1354-1362.

Society for Ecological Restoration International Science and Policy Working Group. 2004. The SER International Primer on Ecological Restoration [on line]. Society for Ecological Restoration International (URL: http://www.ser.org/content/ecological_restoration_primer.as).

Sutherland WJ and others (44 authors). 2009. One hundred questions of importance to the conservation of global biological diversity. Conserv Biol 23:557-567.

Tallis H, Kareiva P, Marvier M, Chang A. 2008. An ecosystem services framework to support both practical conservation and economic development. Proc Natl Acad Sci USA 105:9457-9464. 
991

992

993

994

995

996

997

998

999

1000

1001

1002

1003

1004

1005

1006

1007

1008

1009

1010

1011

1012

1013

1014

1015

1016

1017

1018

1019

1020

1021

1022

1023

1024

TEEB. 2010. The Economics of Ecosystems and Biodiversity: Mainstreaming the Economics of Nature: A synthesis of the approach, conclusions and recommendations of TEEB. URL: http://www.teebweb.org/.

Thiere G, Milenkovski S, Lindgren PE, Sahlen G, Berglund O,Weisner SEB. 2009. Wetland creation in agricultural landscapes: Biodiversity benefits on local and regional scales. Biol Cons 142:964-973.

Thomson JR, Moilanen A, Vesk PA, Bennett AF, Mac Nally R. 2009. Where and when to revegetate?: a quantitative method for scheduling landscape reconstruction. Ecol Appl 19:817-827.

Tisdell C. 2003. Socioeconomic causes of loss of animal genetic diversity: analysis and assessment. Ecol Econ 45:365-376.

Turner MG. 2010. Disturbance and landscape dynamics in a changing world. Ecology 91:2833-2849.

Tscharntke T, Klein AM, Kruess A, Steffan-Dewenter I, Thies C. 2005. Landscape perspectives on agricultural intensification and biodiversity - ecosystem service management. Ecol Lett 8:857-874.

UK National Ecosystem Assessment, 2011. The UK National Ecosystem Assessment: Synthesis of the key findings. UNEP-WCMC, Cambridge.

Vandermeer J, I. 2007. The agricultural matrix and a future paradigm for conservation. Conserv Biol 21:274-277.

Vandermeer J, Perfecto I. 1995. Breakfast of Biodiversity: The Truth about Rainforest Destruction. Food First Books, Oakland, CA, USA.

van Noordwijk M. 2002. Scaling trade-offs between crop productivity, carbon stocks and biodiversity in shifting cultivation landscape mosaics: the FALLOW model. Ecol Model 149:113-126.

Vieira DLM, Holl KD, Peneireiro FM. 2009. Agro-successional restoration as a strategy to facilitate tropical forest recovery. Restor Ecol 17:451-459.

Vorosmarty CJ, McIntyre PB, Gessner MO, Dudgeon D, Prusevich A, Green P, Glidden S, Bunn SE, Sullivan CA, Liermann CR, Davies PM. 2010. Global threats to human water security and river biodiversity. Nature 467:555-561.

Wendland KJ, Honzak M, Portela R, Vitale B, Rubinoff S, Randrianarisoa J. 2010. Targeting and implementing payments for ecosystem services: Opportunities for bundling biodiversity conservation with carbon and water services in Madagascar. Ecol Econ 69:2093-2107. 
1025 Woods J, Williams A, Hughes JK, Black M, Murphy R. 2010. Energy and the food 1026 system. Phil Trans Roy Soc B 365:2991-3006.

1027 WWF. 2010. Living Planet Report 2010. Biodiversity, biocapacity and development [on

line]. WWF, Gland (URL:

1029 http://wwf.panda.org/about_our_earth/all_publications/living_planet_report/).

1030 Zhang W, Ricketts TH, Kremen C, Carney K, Swinton SM. 2007. Ecosystem services 1031 and dis-services to agriculture. Ecol Econ 64:253-260.

1032 Zhang KR, Dang HS, Tan SD, Wang ZX, Zhang QF. 2010. Vegetation community and 1033 soil characteristics of abandoned agricultural land and pine plantation in the Qinling 1034 Mountains, China. For Ecol Manage 259:2036-2047.

1035 Ziegler, A.D., Fox, J.M., Webb, E.L., Padoch, C., Leisz, S.J., Cramb, R.A., Mertz, O., 1036 Bruun, T.B., Vien, T.D., 2010. Recognizing contemporary roles of swidden 1037 agriculture in transforming landscapes of southeast Asia. Conservation Biology 25, 1038 846-848.

1039 
1041 Figure 1. Global amount of total agricultural area, agricultural irrigated area, organic 1042 agricultural area, total forest area, forest plantation area, secondary forest area, and 1043 ecological footprint in the last few decades. Sources: FAOSTAT 2011

1044 (http://faostat.fao.org) for data on total agricultural area and agricultural irrigated area, 1045 updated to year 2008; The World of Organic Agriculture. Statistic and Emerging Trend 1046 2009, IFOAM, Bonn and FiBL, Frick (http://www.ifoam.org/), for organic agricultural 1047 area; FAO (2011) for data on forest area. The observed trends indicate a general 1048 increase in total agricultural area, which peaked in 2001, irrigated agricultural area - an

1049 indicator of agricultural intensification-, and forest plantation area, which mitigates the 1050 loss of total forest area. The proportion of organic agricultural area is marginal.

1051

1052 Figure 2. Sketch of a real restoration project based on a range of land sharing types and 1053 actions - that are explained in the main text - intended to enhance the farmed 1054 environment, which is run by the Fundación Internacional para la Restauración de los 1055 Ecosistemas (www.fundacionfire.org) in Valdepeñas (central Spain). This and similar 1056 projects have been acknowledged as among the best 13 projects that reconcile 1057 agricultural production and biodiversity conservation in this country. The 2-ha field 1058 mostly consists of a certified organic olive grove (type c in the text), which was 1059 established after a one-year fallow period (type b). A row of singular fruit tree 1060 seedlings, i.e. from healthy and locally adapted variety fruit trees, of three different 1061 species is inter-cropped with the dominant olive tree crop (types a and d). The following 1062 specific elements (type e) have been introduced in the crop system to benefit wildlife 1063 and particular services (mentioned in parenthesis): (1) a hedge row plantation consisting 1064 of ca. 1,100 seedlings of ten native species in the region (to mitigate soil erosion, 1065 abrasion of the crop, attraction of pollinators and natural enemies, community 
1066 diversification, and seed exportation to accelerate passive restoration of nearby

1067 abandoned cropland, a way of land separation); (2) a pond (chiefly to favour amphibians

1068 and birds, particularly game species such as the red-legged partridge Alectoris rufa,

1069 which are an input to the local economy); (3) perch and nest boxes (enhancement of

1070 small birds of prey that are intensive rodent consumers); (4) conditioning of stone

1071 mounds (creation of habitat and refuges for wildlife); and (5) construction of a stone

1072 hut, a jewel of the local rural architecture (enhancement of the cultural value of this

1073 project).

1074

1075 Figure 3. Simulation of the large area (ca. $1.6 \mathrm{~km}^{2}$ ) that could potentially receive acorn

1076 rain following European jay dispersal from two introduced woodland islets (as shown in

1077 the upper photograph) or living fences one $\mathrm{km}$ apart from each other in a deforested

1078 agricultural landscape located in central Spain. The reported figure derives from an

1079 estimated dispersion distance of $500 \mathrm{~m}$ from each woodland islet or living fence (Purves

1080 and others 2007). Without the introduction of these elements, acorn rain and

1081 subsequently oak regeneration would not occur because native vegetation has been

1082 virtually extirpated in vast areas of this region. 
Table 1. Statistics, for 20 selected countries that are representative of different economies in the world, on: ecological footprint, percentage of cropland and grassland footprint on ecological footprint, percentage of area of agricultural land, total forest and forest plantations, and their changes, in the last few decades, and Gross Per Capita Domestic Product. Sources: Footprint Network (http://www.footprintnetwork.org/) for ecological footprint data; FAOSTAT 2011 (http://faostat.fao.org) for percentage of area of agricultural land and its change, updated to year 2008; FAO (2011) for percentage of area of total forest and forest plantations in 2010 and their changes as well as for GDP.

\begin{tabular}{|c|c|c|c|c|c|c|c|c|c|c|}
\hline Country & $\begin{array}{l}\text { Ecological } \\
\text { footprint } \\
2007 \\
\text { (global } \\
\text { ha/person) }\end{array}$ & $\begin{array}{l}\text { Cropland } \\
\text { footprint } \\
2007(\%)\end{array}$ & $\begin{array}{l}\text { Grassland } \\
\text { footprint } \\
2007(\%)\end{array}$ & $\begin{array}{l}\text { Agricultural } \\
\text { area (2008; } \\
\% \text { on land } \\
\text { area) }\end{array}$ & $\begin{array}{l}\text { Change in } \\
\text { agricultural } \\
\text { land area } \\
\text { (\% since } \\
1961)\end{array}$ & $\begin{array}{l}\text { Total } \\
\text { forest } \\
\text { area } \\
(2010, \\
\% \text { on } \\
\text { land } \\
\text { area) } \\
\end{array}$ & $\begin{array}{l}\text { Forest } \\
\text { plantations } \\
\text { area }(2010, \\
\% \text { on total } \\
\text { forest } \\
\text { area) }\end{array}$ & $\begin{array}{l}\text { Change } \\
\text { in total } \\
\text { forest } \\
\text { area } \\
(\% \\
\text { since } \\
1990) \\
\end{array}$ & $\begin{array}{l}\text { Change in } \\
\text { forest } \\
\text { plantation } \\
\text { area (\% } \\
\text { since } \\
1990)\end{array}$ & $\begin{array}{l}\text { Grosse } \\
\text { per } \\
\text { capita } \\
\text { domestic } \\
\text { product } \\
\text { (USD) }\end{array}$ \\
\hline Afghanistan & 0.6 & 53.33 & 25 & 58.2 & 0.56 & 2 & --- & 0.00 & ---- & 1103 \\
\hline Brazil & 2.9 & 24.83 & 32.08 & 31.27 & 75.71 & 62 & 1 & -8.86 & 15 & 10304 \\
\hline Canada & 7.0 & 13.57 & 3.71 & 7.43 & -3.19 & 34 & 3 & 0.00 & 586 & 39078 \\
\hline China & 2.2 & 24.09 & 5 & 56.02 & 52.24 & 22 & 37 & 28.12 & 39 & 5971 \\
\hline Colombia & 1.9 & 20.53 & 39.47 & 38.4 & 6.61 & 55 & 1 & -2.91 & 356 & 8797 \\
\hline Germany & 5.1 & 24.51 & 4.11 & 48.54 & -12.66 & 32 & 48 & 3.12 & 1 & 35374 \\
\hline Guatemala & 1.8 & 23.89 & 12.22 & 39.36 & 59.41 & 34 & 5 & -20.61 & 365 & 4760 \\
\hline India & 0.9 & 43.33 & 0.04 & 60.44 & 2.74 & 23 & 16 & 6.58 & 68 & 2946 \\
\hline Jamaica & 1.9 & 27.89 & 5.26 & 42.84 & -12.95 & 31 & 2 & -1.93 & -23 & 7716 \\
\hline Mali & 1.9 & 38.42 & 43.68 & 32.48 & 25.02 & 10 & 4 & -10.12 & 11158 & 1129 \\
\hline
\end{tabular}




\begin{tabular}{|c|c|c|c|c|c|c|c|c|c|c|}
\hline Mexico & 3.0 & 27.67 & 10.66 & 52.73 & 4.33 & 33 & 5 & -7.37 & $232 *$ & 14570 \\
\hline Nepal & 3.6 & 10.28 & 1.38 & 29.44 & 19.23 & 25 & 1 & -24.52 & 20 & 1104 \\
\hline Russia & 4.4 & 20.23 & 2.27 & 13.16 & -2.77 & 49 & 2 & -0.01 & 28 & 15923 \\
\hline Serbia & 2.4 & 27.92 & 2.5 & 57.22 & -0.20 & 31 & 7 & 3.76 & 353 & 10554 \\
\hline Spain & 5.4 & 26.85 & 5 & 55.90 & -16.04 & 36 & 15 & 28.97 & 2 & 31674 \\
\hline United & 10.7 & 12.62 & 3.85 & 6.82 & 174.04 & 4 & 100 & 28.65 & 0.00 & 37442 \\
\hline \multicolumn{11}{|l|}{ Arab } \\
\hline \multicolumn{11}{|l|}{ Emirates } \\
\hline Thailand & 2.4 & 24.17 & 0.83 & 38.46 & 68.63 & 44 & 21 & -3.10 & 54 & 8086 \\
\hline Togo & 1.0 & 31 & 0.9 & 66.74 & 18.24 & 5 & 15 & -52.32 & 328 & 830 \\
\hline UK & 4.9 & 17.76 & 5.51 & 73.10 & -10.69 & 12 & 77 & 9.79 & 2 & 35468 \\
\hline USA & 8.0 & 13.50 & 1.75 & 44.95 & -8.11 & 33 & 8 & 2.34 & 32 & 46350 \\
\hline
\end{tabular}

* Change since 2000 


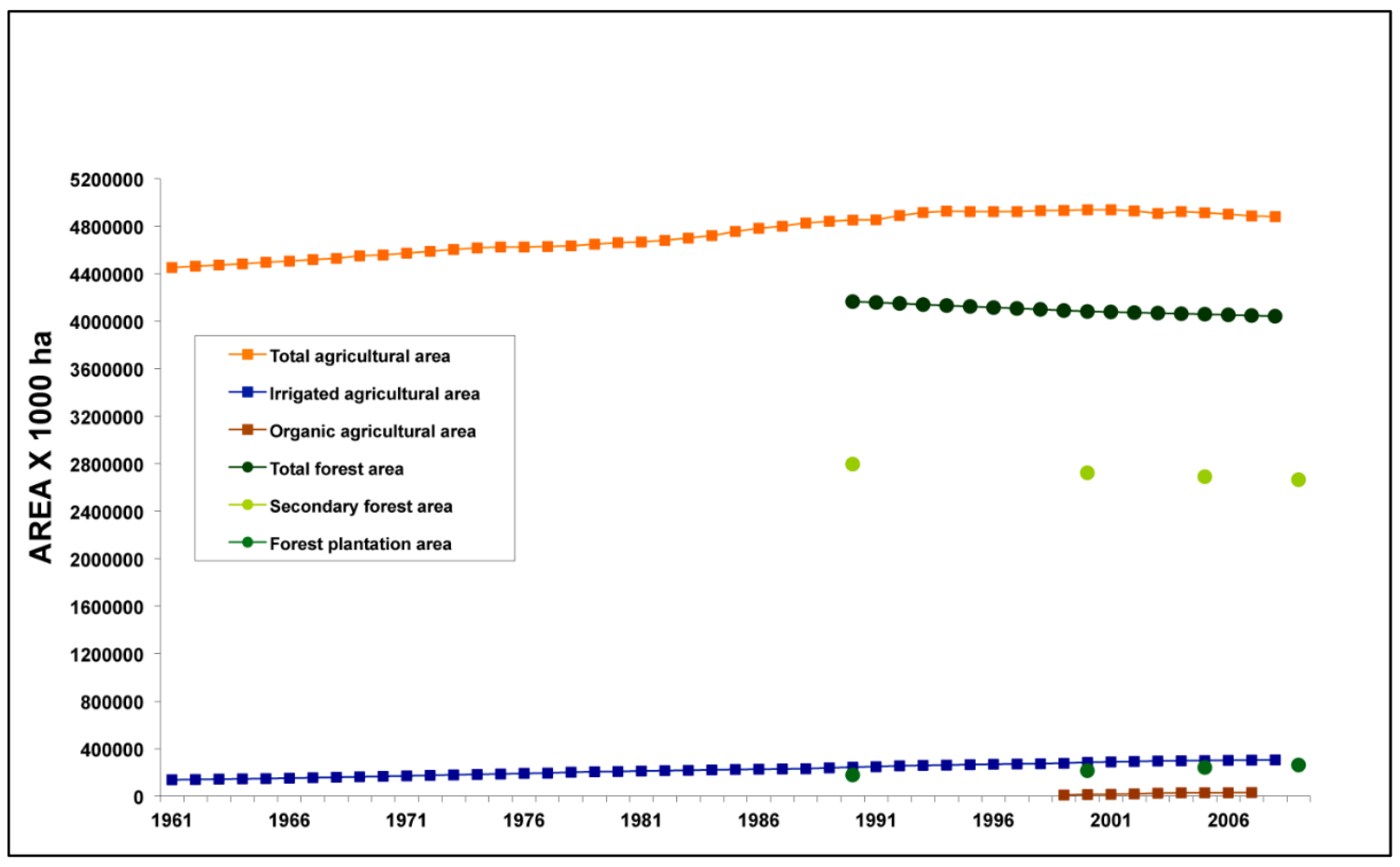

Fig. 1 


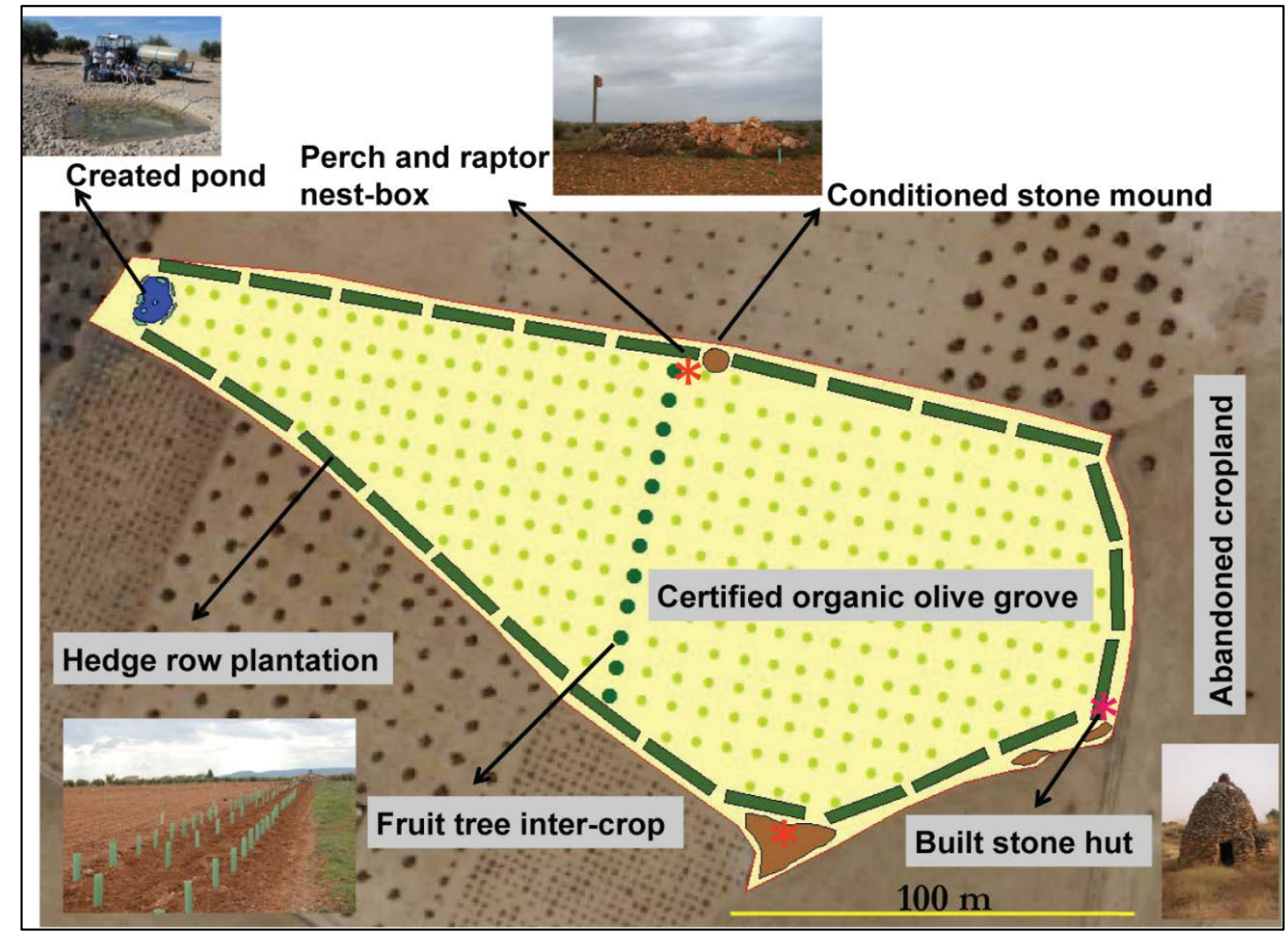

Fig. 2 


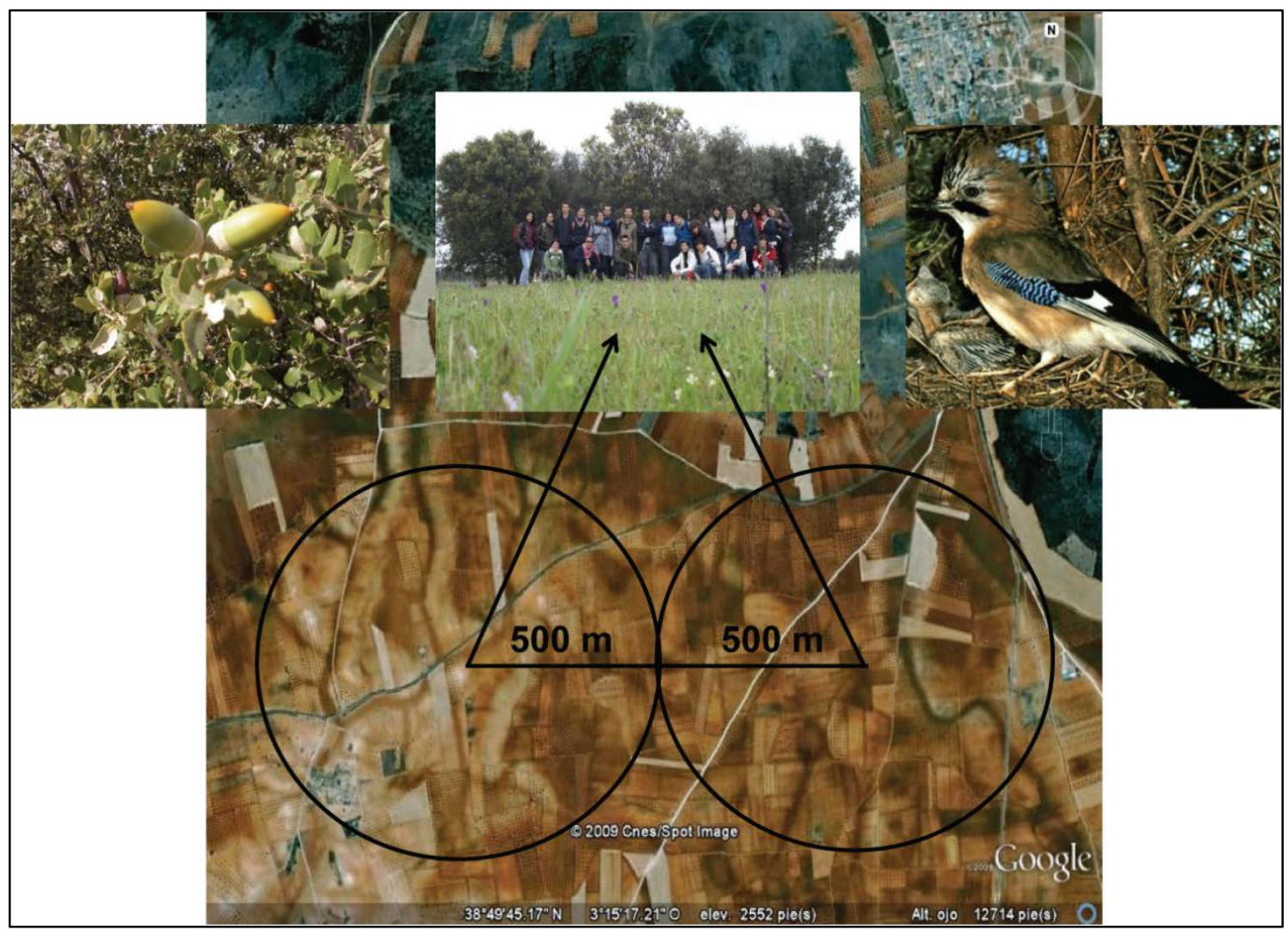

Fig. 3 